\title{
VATRA DORNEI - FORESTRY LANDSCAPE DYNAMICS IN THE PAST 240 YEARS
}

DOI: http://dx.doi.org/10.18509/GBP.2018.62

UDC: 502.211:630*1]:528.94(498)

\author{
Afloari Mihai \\ Graur Diana-Sofia \\ Horodnic Vasilică-Dănuț \\ Efros Vasile \\ "Stefan cel Mare" University of Suceava, Faculty of History and Geography, \\ Department of Geography, 13 Universitatii, Suceava, Romania
}

\begin{abstract}
In the last 240 years Vatra Dornei passed many types of politic forms. From a socioeconomic and political point of view during the 240 years, Vatra Dornei represented a obvious development in accordance with the specific potential of Dorna Land, especially mineral and forest resources.

Regarding the dynamics of the forest landscape, Vatra Dornei presents an eloquent example of different forms of management of forest areas influenced by: patrimony factors, political decision factors, natural factors, demographic evolution (pressure on the forest landscape).

By cartographical statistical, mathematical and aerophotographic models, this study exemplifies the dynamics of this type of landscape in different stages of political and administrative evolution of imperialist, monarchist, totalitarian and capitalist order.
\end{abstract}

Keywords: Vatra Dornei, forest landscape, dynamics, influence factors, cartographic modeling

\section{INTRODUCTION}

Description of the forestry landscape can be achieved by using a few terms. To describe these terms, we must analyze photographs and sketches. But not even these materials don't complete the three-dimensional reality of the landscape.

In addition to reduce the number of terms selected to define and applicate, we have to accept another restriction, that the landscape represents a physical, visual, entity and not an abstract emotional quality.

We could say that vegetation is the main source of contrast due to changes in surface.

Trees can be primary forms in the landscape, even if they are in limited groups or as individuals. And the vegetal cover can appear as a model of two-dimensional forms placed over the three-dimensional base [1].

În unele zone exploatate, partea formantă a structurii vegetaţiei este vizibilă, dar principala diferenţă între peisajele exploatate și cele naturale au fost detectate în împrejurimile și dimensiunile standurilor de păduri de conifere climatice [2].

The scientific motivation is expressed by the desire to expose new elements to the geographic studies elaborated in the researched area. Up to now there have been mentioned in various studies, aspects of the physical-geography framework or aspects of 
human geography, but studies regarding geographical evolution landscapes in the municipality of Vatra Dornei have not been elaborated yet.

The main purpose of the study is to highlight the detailed cartographical products (topographical / aerial images) with regard to the structural changes of the visible part of the geographic landscape in Vatra Dornei municipality [3].

We also followed the argumentation on statistical bases extracted from the topographic plans regarding the quantitative and qualitative transformations of the geographical landscape in the researched area and discovering the socio-geosystems dynamics level of the entities of Dorna's geographical landscape.

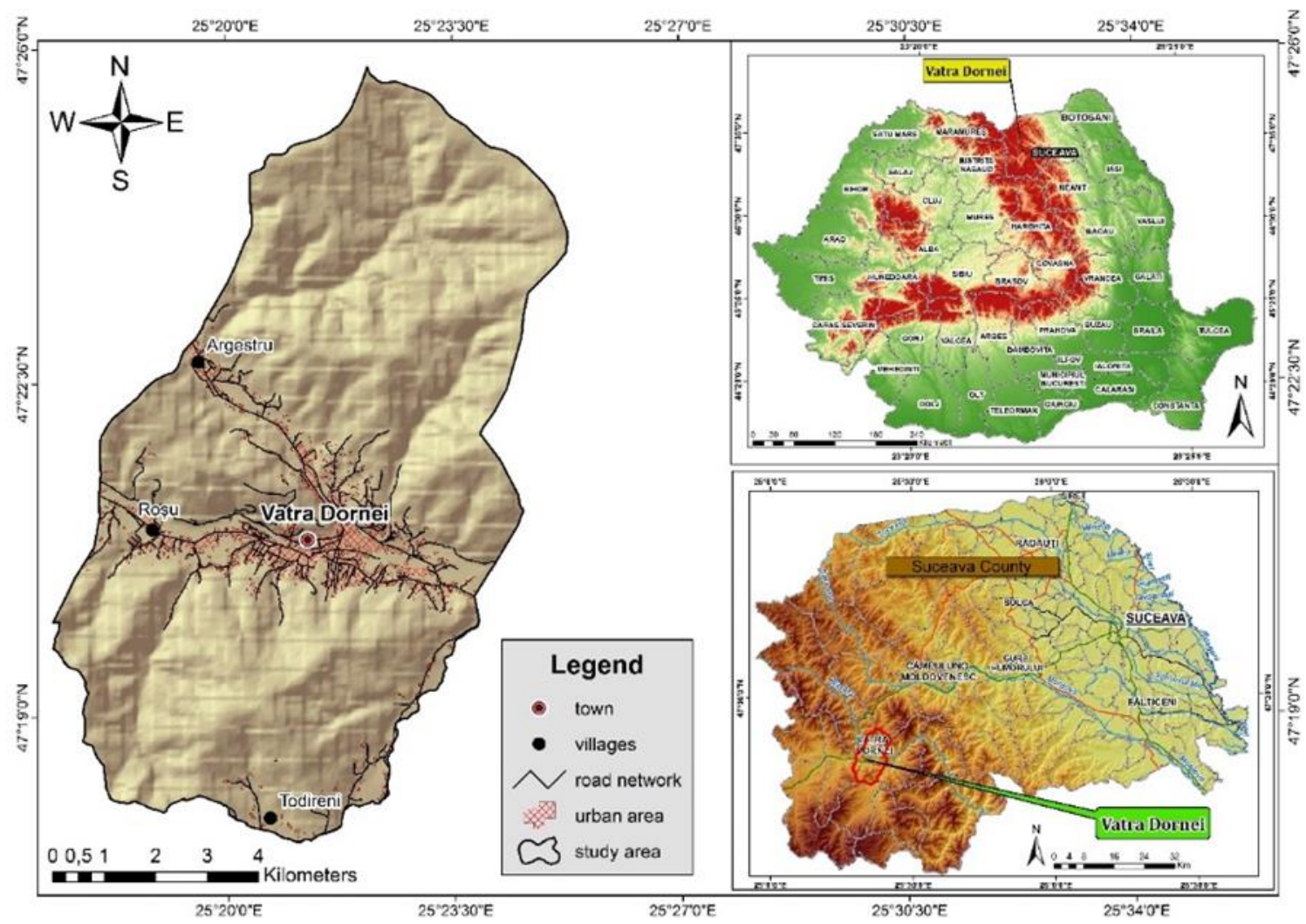

Figure 1. The location of study area

The theoretical relevance of the study is based on the presentation of topographical and cadastral plans as valuable sources of geographical information that can be analyzed through GIS programs and geographical expertise. [4]

Regarding the practical relevance of this study, we can state that these processed cartographical data sets can be extremely useful, especially on decision-makers in the field of administration, landscape designers, environmental specialists, etc. [5]

\section{Cartographical products used}

For the elaboration of this study we used a series of cartographical products, elaborated in different historical periods. So we chronologically used the following sets of maps:

- Austrian maps from 1778 at 1:28 800;

- Austrian cadastral plans from 1856 at 1: 2880 scale;

- the topographical map of Romania from 1984 at 1: 25000 scale;

- ANCPI (the Agency of the National Cadastre and real Estate Advertising) aerial photo plans from 2005. 


\section{Study area}

Vatra Dornei is located in the southwestern part of Suceava county, north of Romania. The study area is located in Dorna basin at the confluence of the rivers Dorna and Bistrita, surrounded by the Suhard Mountains in the northwest, the Giumalău Massif in the northeast and the Călimani Massif in the southwest and south [6].

\section{Geomorphological description}

Vatra Dornei is situated at an average altitude of $804 \mathrm{~m}$ and the surrounding mountain massifs reach average elevations above $1300 \mathrm{~m}$. From a morphological point of view, the Dorna basin area is a flattened "tectonics-erosion". [7], [8], [9]

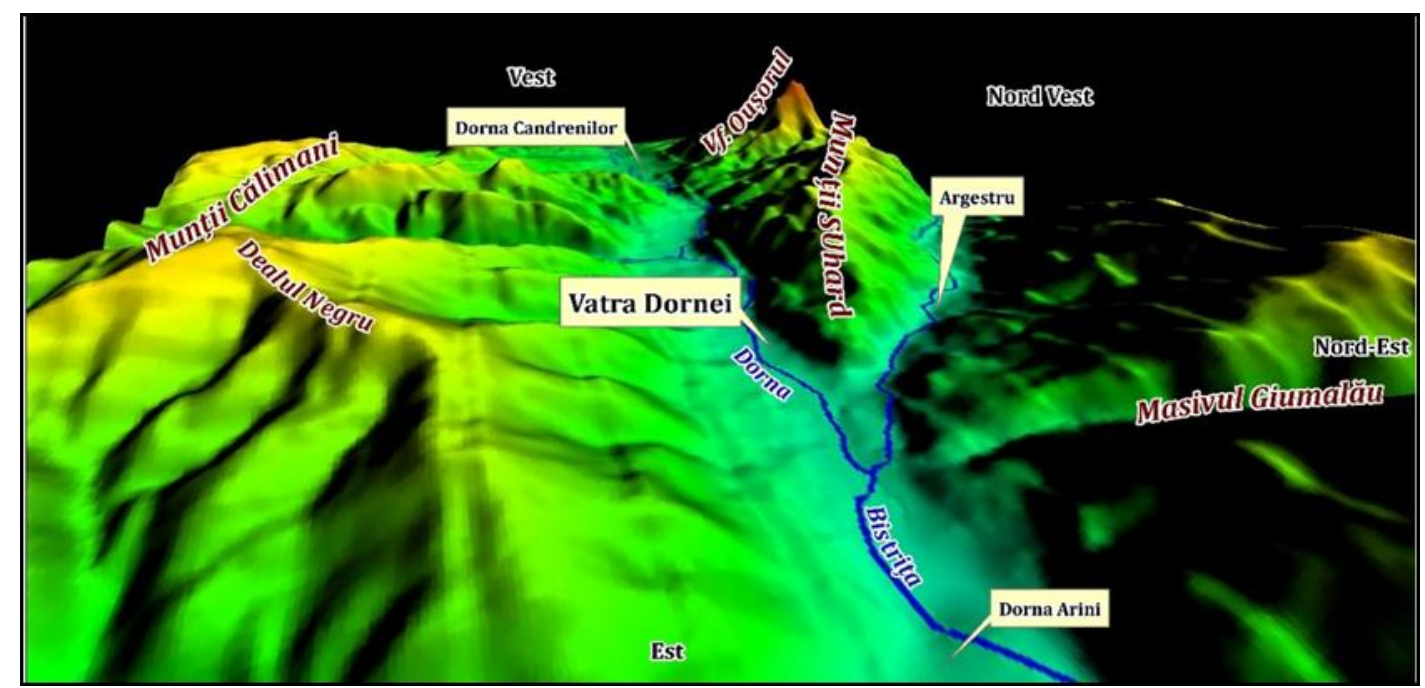

Figure 2. 3D numerical model of the Dorna basin - eastern part view towards Vatra Dornei

Researchers say that "the Sarmatian plains deposited by Bistrita in front of the Carpathians could not have been brought from Căliman through the Bistricioarei network but through the rivers that gathered in the low area of Vatra-Dornei", this explains the large basin to the western part and strait to the eastern part of the basin [10], [11],], [12].

Forestry characteristics

The natural vegetation in the geographical area of Vatra Dornei is represented by spruce stand (800-1300m), mountain meadows and natural hay fields. The predominant species are Picea abies, Abies alba, and the grassy vegetation of the species Carex curvula, Poa alpina, and Festuca supine.

The forest and natural hayfields are the main elements of the natural vegetation in the Dorna area, which have directed certain meanings of development and evolution of geographic landscapes.

These elements of natural vegetation represent a resource for both domestic and industrial purposes. Regarding the abundance of forest areas, they account for over $55 \%$ of the administrative area of Vatra Dornei, and natural meadows over $35 \%$.

Since the ancient times for the Dorna area, but also today, wood processing and animal husbandry are the main fields of activity. Wood is the raw material in local industrial activities, but also it is used at the thermal power station of Vatra Dornei [13]. 


\section{METHODS}

Several stages and study methodologies have been carried out to accomplish this paper. Initially, it was necessary to collect the data by identifying the documents, which are the main source of the cartographic data sets.

The first set of data, Austrian maps from 1778 at the 1:28 800 scale, required scanning operations to be able to use an electronical cartographical file to be processed in geographical analysis system.

The Austrian cartographic data sets from 1778 and 1856, were georeferenced to be assigned a new projection in accordance with the Romanian National Coordinate System in Stereo 70 coordinates[14].

In order to produce the final cartographic products, through maps of the geographical landscapes in Vatra Dornei, we have grouped following land use types (cultural anthropic landscape, cultural pastoral landscape, natural forest landscape, natural water scenery), where the dynamics of the natural forest landscape are representing the subject of study. Until the elaboration of the paper in the final form, we went through stages of analysis of the existing bibliography, related to the topic of the present study. For example, Nicolae Baciu states that in landscape geography "for a long time landscape science has been closely linked to the landscape geography, trying to solve the dichotomy between Naturlandschaft and Kulturandschaft created by the beginnings of the landscape approach to the German school."[15], [16], [17]

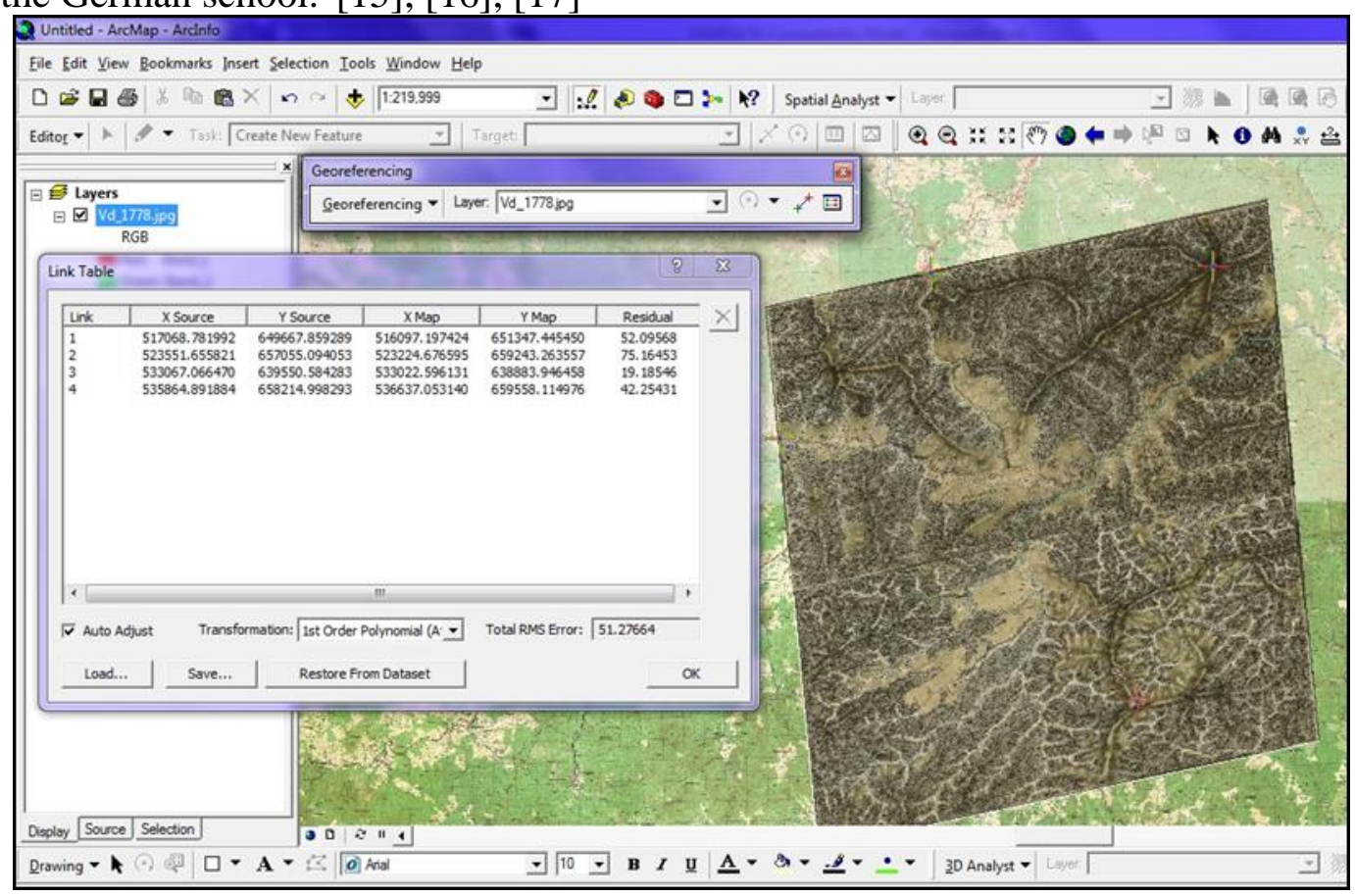

Figure 3. Expressed values of georeferencing errors in Arc Gis, for the Austrian map of 1778

In his PhD thesis, Traian Crăcea, quotes Vintilă Mihăilescu (1968) on the evolution of the concept of geographical landscape, as geography is considered to be the "scientific description and explanation of the landscapes", and the geographical landscape as considered as "the outer character set, specific of a territory, human society being a part of the geosystem as a product and an active factor integrated into that geosystem" [18]. 


\section{RESULTS}

The forest as a natural landscape entity, fulfills a number of multiple functions thus forming an ecosystem. The nature was generous with the mountain area of Dorna regarding the natural forest data, which is why this type of landscape was exploited for various purposes and intensities depending on the population percentage of the Dorna geographical space.

\section{Analysis of the year 1778}

According to the final cartographic products, based on the Austrian-Hungarian topographic map at 1:28 800 scale from 1778, a dominant layout of the landscape of green dominance of natural forest type or pastoral natural-cultural is emerging.

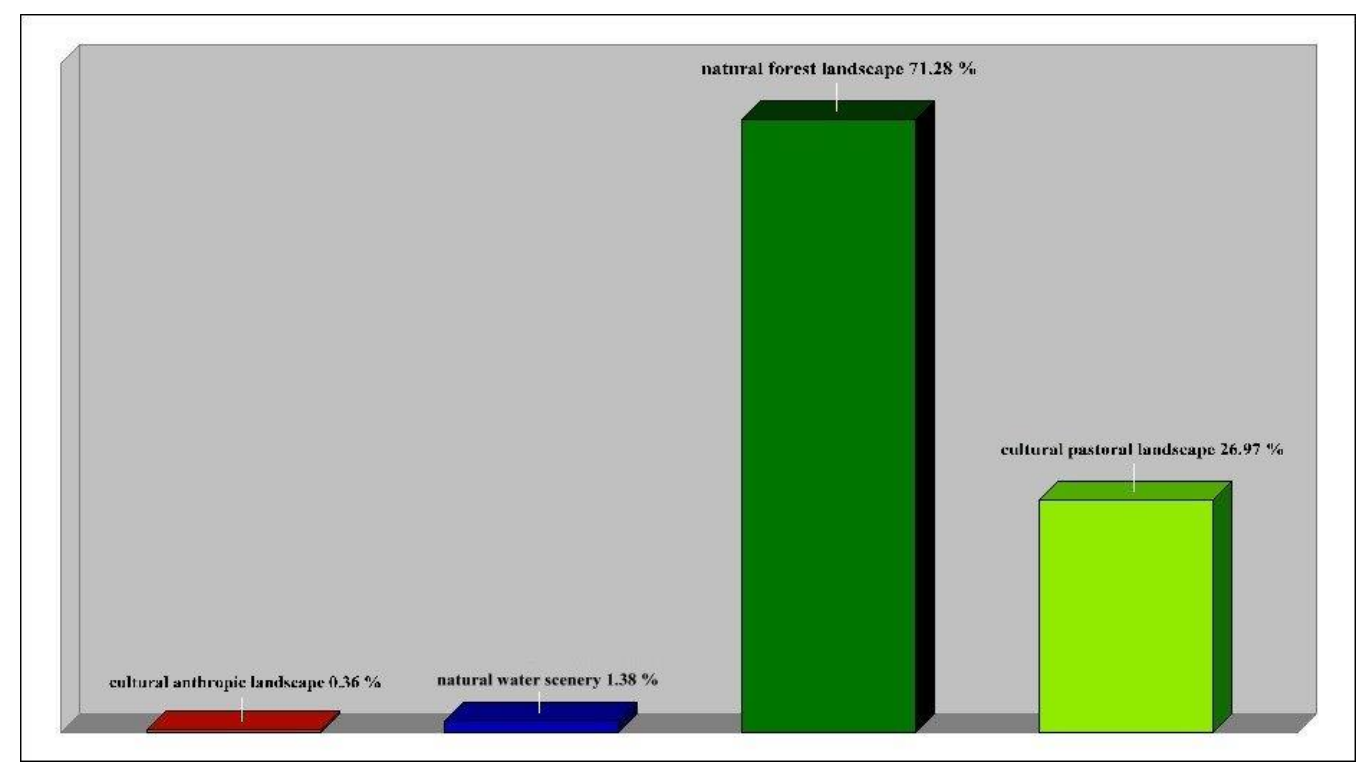

Figure 4. Percentage of geographical landscapes types in Dorna Watra Szatului, 1778

In 1778 the population of Dorna was about 409 inhabitants, and that explains the low percentage of population in Dorna. From a total area of $99.89 \mathrm{~km}^{2}$, only an area of 0.3 $\mathrm{km}^{2}$ is marked by the level of population number in Dorna, during this period of analysis.

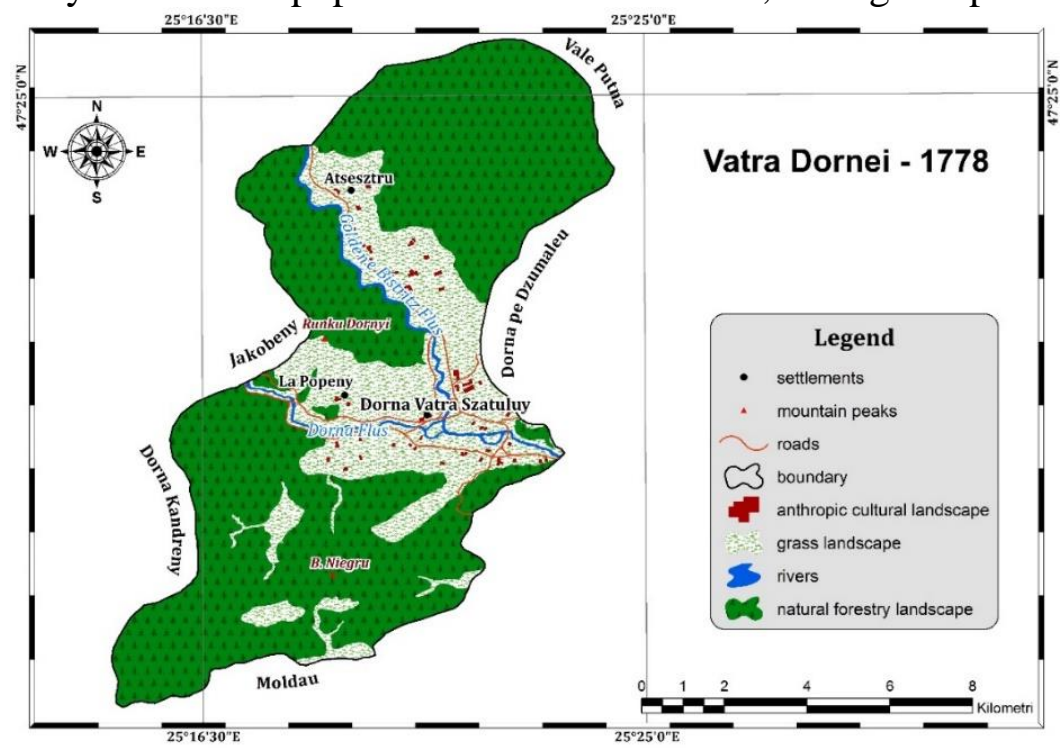

Figure 5. Cartographic representation of geographical landscapes types areas in Dorna Watra Szatului, 1778 


\section{Analysis of the year 1856}

According to the cartographic analysis of 1856,it can be observed that Dorna Watra with its under administrative structures is similar to the analysis period from 1778. The abundance of the landscape of green dominance of natural forest type and the naturalcultural pastoral it is similar.

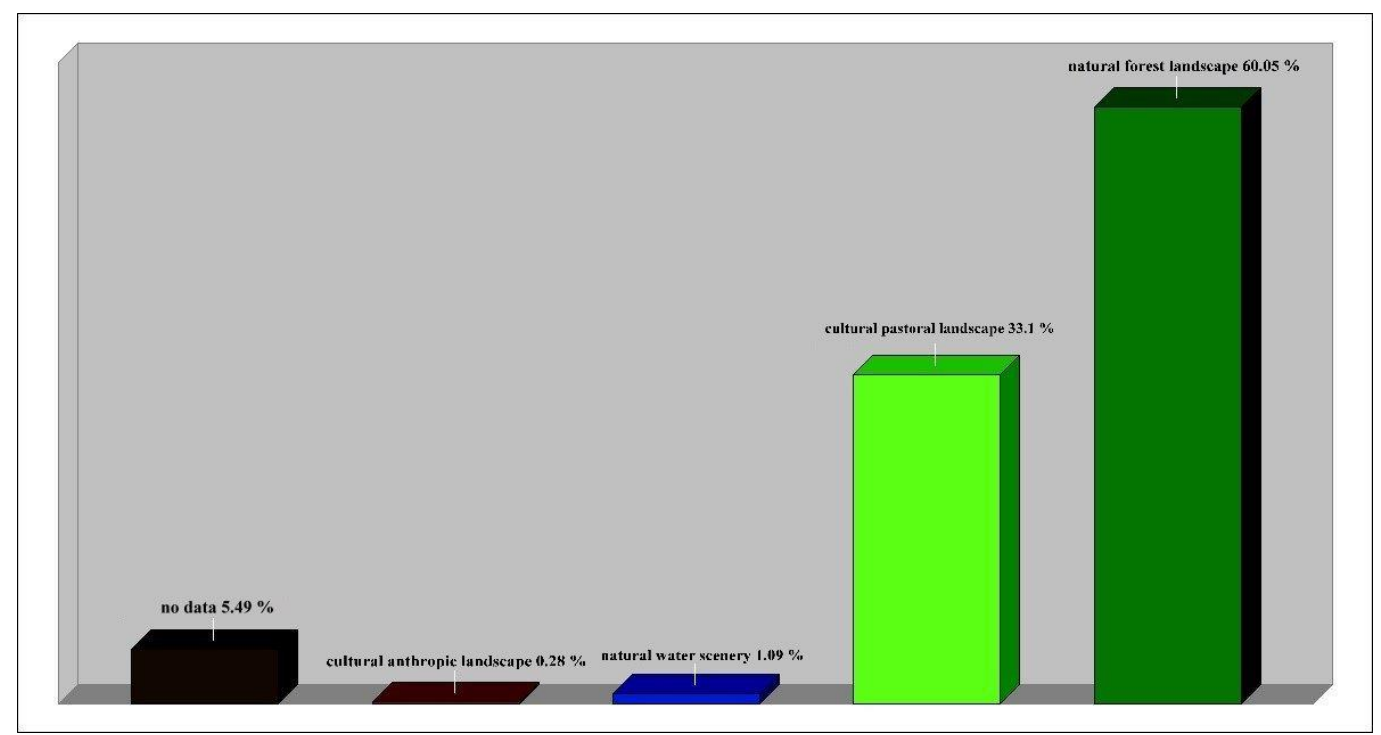

Figure 6. Percentage of geographical landscapes types in Dorna Watra, 1856

The issue of cartographic analysis of 1856 is found in the absence of sheets 35-36 from the Austrian cadastral base from 1856.

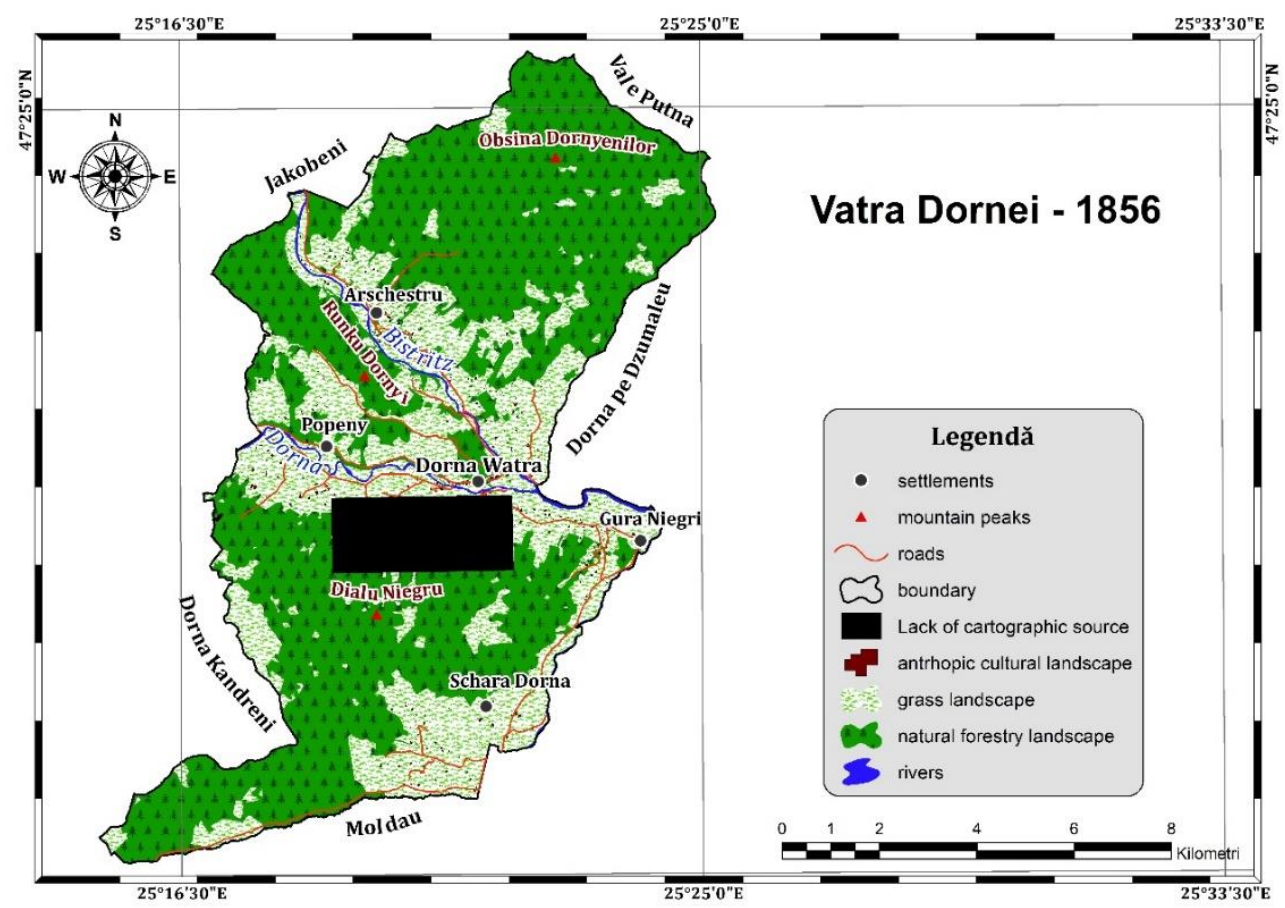

Figure 7. Cartographic representation of geographical landscapes types in Dorna Watra in 1856

There was a reduction of the surface area of the natural forest landscape by about $11 \%$ and the increase of the landscapes of the pastoral natural-cultural landscape by about $6 \%$, 
which is considered to be normal in the context of the increase of the number of inhabitants and the intensification of the zootechnical activities in the area.

\section{Analysis of the year 1984}

The graphical and cartographical representations indicate structural changes of the Dorna geographical landscape at the quantitative and qualitative level. The geographical landscape structure of Dorna in 1984 corresponds to the trend of increasing population area, and the decrease of the natural geographical landscapes.

Compared to 1856 , the analytical results of 1984 indicate a $3 \%$ decrease in the natural forest landscape and a $6 \%$ increase in the pastoral natural-cultural landscape.

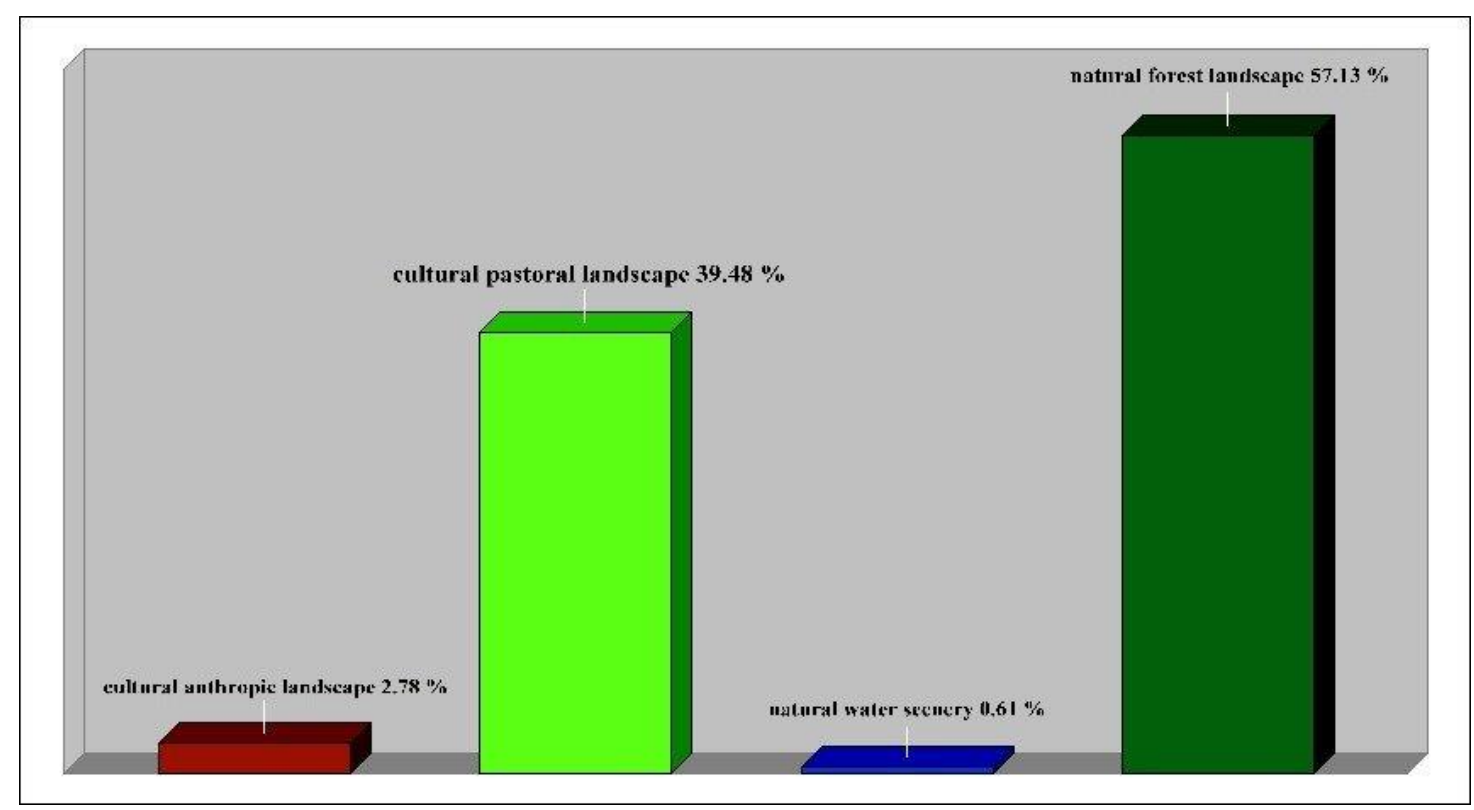

Figure 8. Percentage of geographical landscapes types in Dorna Watra, 1984

On the cartographical plan it can be observed that the population area is increasing in the area of river meadow and lower terraces on the territory of Vatra Dornei, whitin the natural-cultural landscape, and the natural forest landscape surface is decreasing.

The natural forest landscape has been changed in order to being build one of the longest ski slopes in the country for over $3 \mathrm{~km}$ in the Black Hill area. Also, through the deforestation and land stabilization works, there were built Park 1 and Park 2. 


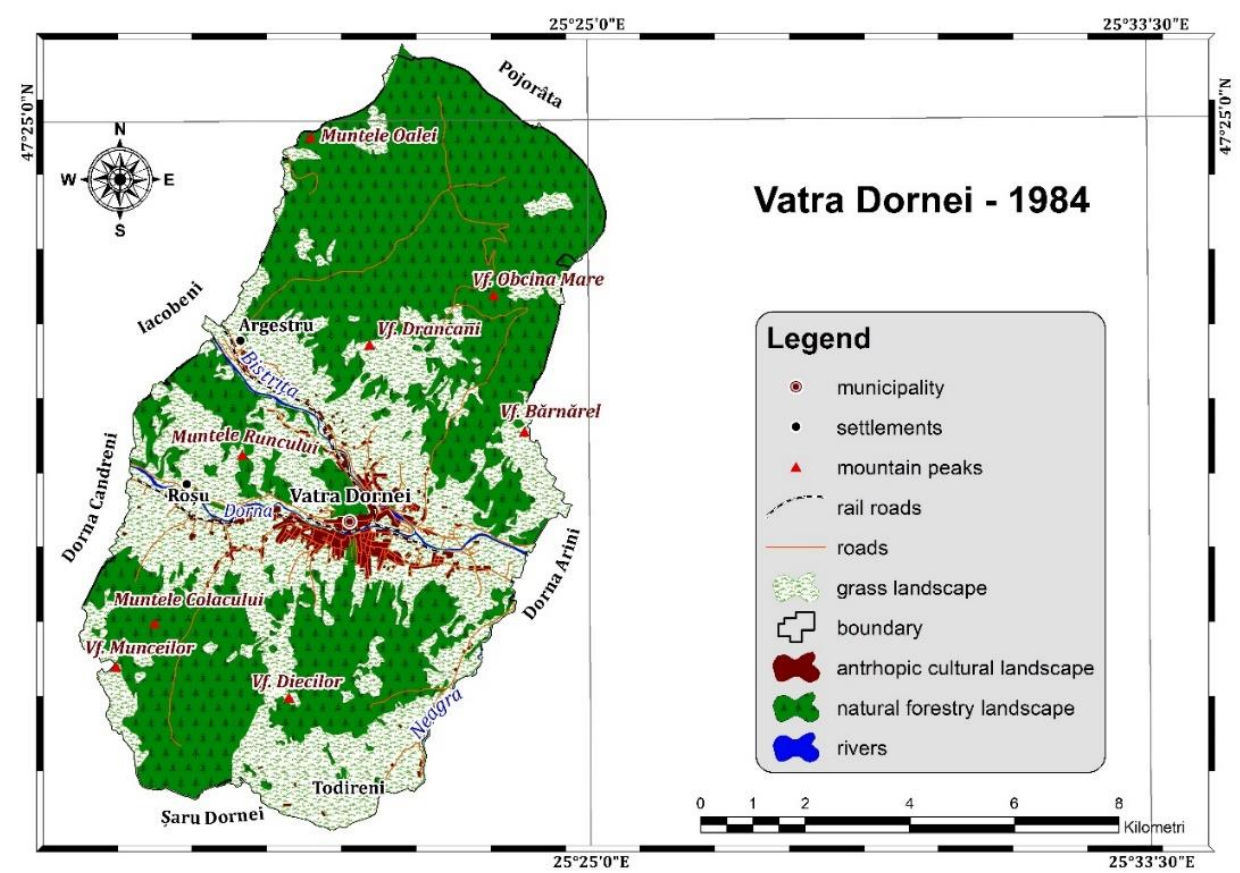

Figure 9. Cartographic representation of geographical landscapes types in Vatra Dornei in 1984

\section{Analysis of the year 2005}

Vatra Dornei's landscaping structure in 2005 corresponds to the expected evolution trend. There was an increasing of the anthropic cultural landscape area at the expense of the quantitative - qualitative evolution in the natural landscape.

Although, according to the 2002 census, the population of Vatra Dornei recorded a percentage decrease of about $11 \%$, the quantitative and qualitative changes in the structure of the Dorna's geographical landscape indicate an increasing percentage of cultural anthropic landscape. We also notice the decreasing of the natural landscapes of the cultural-pastoral type area and a insignificant increase of the natural forest type area.

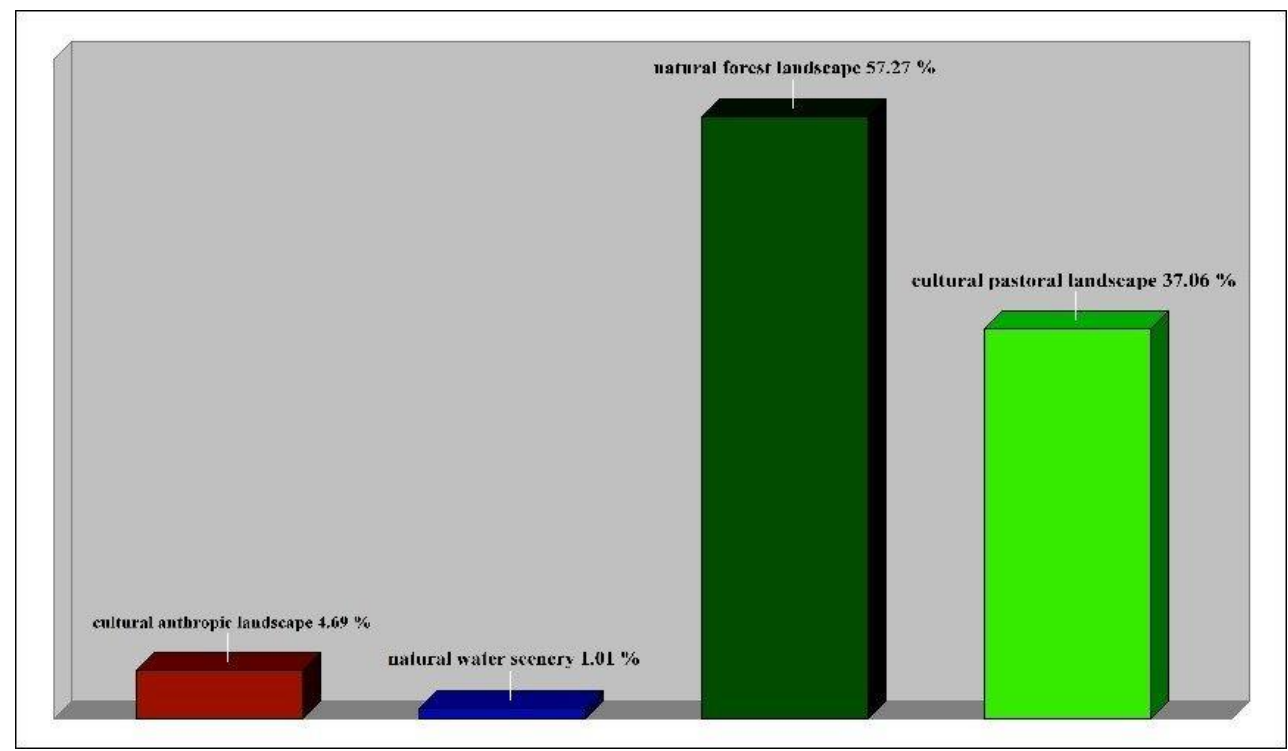

Figure 10. Percentage of geographical landscapes types in Vatra Dornei in 2005 
The natural forest landscape at the level of the territory of Vatra Dornei had a reduced areal evolution, up to $1 \%$ compared to the previous period of analysis, according to the elaborations and cartographical interpretations.

According to the cartographical products in 2005, new forestry areas appears in Vatra Dornei or there have been created reduced forest areas near the town.

The analysis vectors of the temporal and spatial level, expose a descendent character of the changes in the natural forest and the natural - pastoral cultural landscape. The anthropic cultural landscape had an ascending areal evolution according to the anthropical increase level in Dorna's territory.

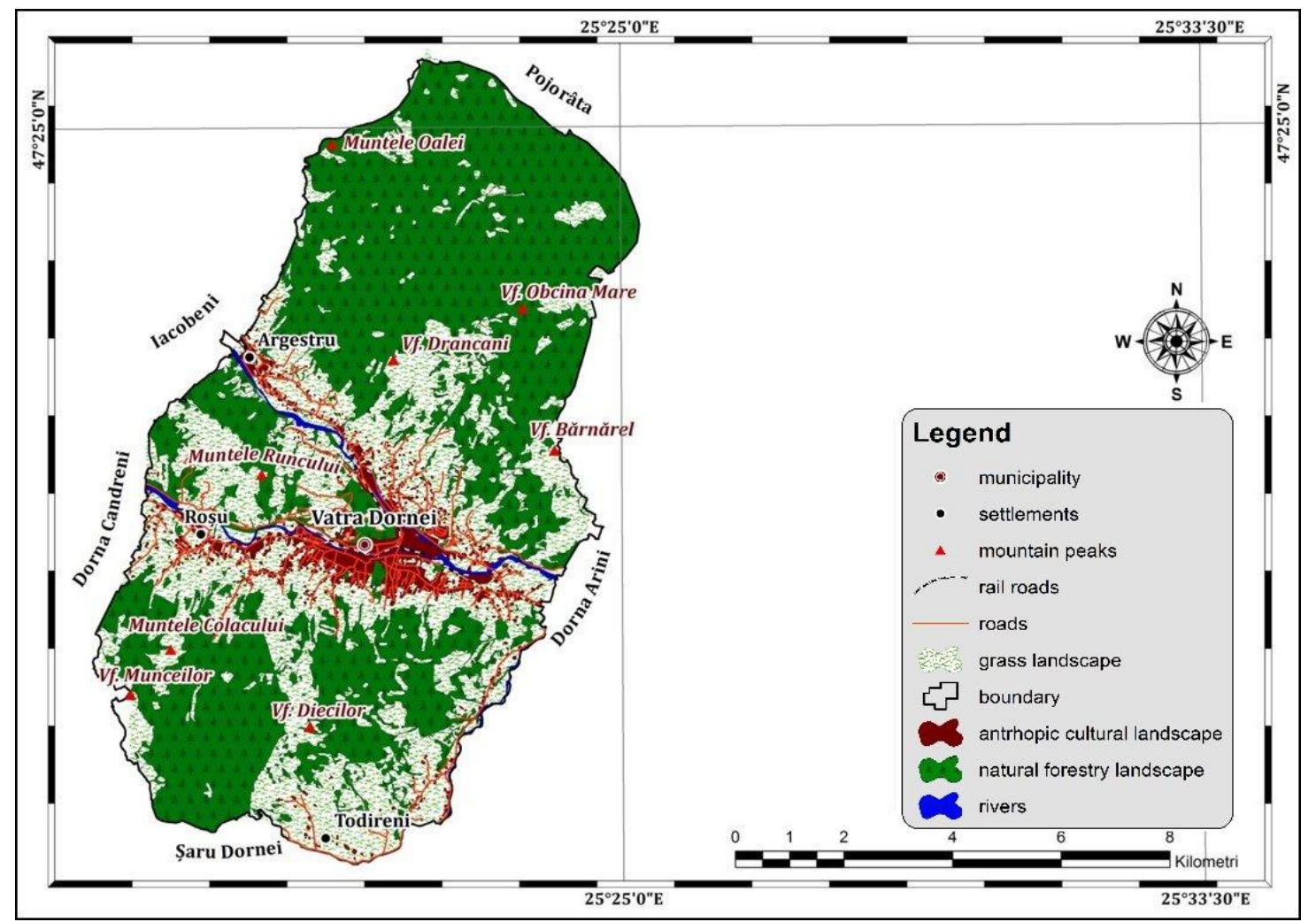

Figure 11. Cartographical representation of geographical landscapes types in Vatra Dornei in 2005

\section{DISCUSSIONS}

The geographic landscapes of Vatra Dornei have been researched from a dynamic perspective by analyzing some cartographic documents from different time periods, so that they can be captured by the essential changes in the different landscape components. The forest as a biotope has greatly reduced its functions (hygienic-sanitary: an environment conducive to maintaining a state of physical and mental comfort for man, antibacterial filter, air ionization, water quality maintenance, protection of hydromineral curative fund) with the forest patrimony.

Breams in the forest of Vatra Dornei were also created by the extension of the ski slopes, the lifts, the tourist routes, the forestry network or other destinations, the extension of the railway network, and electricity transmission lines. 


\section{CONCLUSIONS}

The forest as a exploitable resource has generated the development of the woodworking industry since ancient times with the development of the float in the area. After 1895 construction works were carried out on Bistrita Valley for the accumulation of higher water flows, to facilitate the transport of wood on Bistrita. These activities lasted until 1961 with the commencement of the construction of the Bistrita Izvorul dam from Bicaz, and the construction of modernized roads, which allowed the transport of wood by trucks Throughout the analysis of the evolution of geographical landscapes in vatra Dornei, the forest presented a regime of surface reduction through the evolution of the anthropical cultural landscape area.

The anthropic area (within the 4 maps) recorded, as is normal, an ascending evolution, characterized by the extension of the constructed (or anthropically modified) perimeters from $0.36 \%$ of the total area initially analyzed to $4.69 \%$ in 2005 The decrease in the surface of the anthropic cultural landscape in 1856 is due to the lack of sheets 35 and 36 but also because of the scale differences of the cartographic media used.

There is a significant decrease of the forests areas, from $71 \%$ of the total area from the analysis of 1778 , to $57.24 \%$ in 2005 period.

\section{REFERENCES}

[1] Litton RB. Forest landscape description and inventories-a basis for landplanning and design. Res. Paper PSW-RP-049. Albany, CA: Pacific Southwest Research Station, Forest Service, US Department of Agriculture, U.S.A.,1968 pp 2-13;

[2] Syrjänen K, Kalliola R, Puolasmaa A, Mattsson J. Landscape structure and forest dynamics in subcontinental Russian European taiga. In Annales Zoologici Fennici, . Finnish Zoological Publishing Board, formed by the Finnish Academy of Sciences, Societas Biologica Fennica Vanamo, Societas pro Fauna et Flora Fennica, and Societas Scientiarum Fennica.1994 Jan 1, pp. 19-34;

[3] Baciu N. Landscape's dynamic and tipology(in Romanian), Ed. Bioflux, Cluj-Napoca, Romania, 2014;

[4] Chirita, V. Dornelor Depression-Physico-geographical study(in Romanian), Suceava, Romania, 2003;

[5] Vişan, Elena-Livia. Sectorul montan şi subcarpatic al Văii Prahova: gestiune, evaluare şi prognoză peisagistică, $\mathrm{PhD}$ Thesis(in Romanian), Bucharest, Romania, 2011

[6] Barbu, I., MARIUS CURCA, VIORICA ICHIM, and CATALINA BARBU. Causes of change in the structure of landscapes in Bukowina (1775-2010) (in Romanian). Revista de Silvicultură și Cinegetică 21, no. 38, Romania, 2016, pp 56-65;

[7] Barbu N, Ionesi L, Ionesi BI. Geological and paleogeomorphological observations in the contact area of Obcinele Bucovinei with Suceava Plateau(in Romanian), Romania, 1966;

[8] Juravle DT, Androne DA. Considerations on the palaeogeography of the Suceava valley basin in the Carpathian Fly area(in Romanian). Geographical Seminar "Dimitrie Cantemir", Romania,2005;

[9] Donisă I, Barbu N, Ionesi L.Stages of the evolution of the hydrographic network in the Oriental Carpathians(in Romanian), Romania, 1973;

[10] Sîrcu I. Terrasses fluviales, surfaces d'erosion local et pseudopeneplaines dans le nord du Plateau Moldave, Scientific Annals of the Univ. ". Al. I Cuza ", New Series, Section II-Natural Sciences, b. Geology-Geography,Romania, 1965, pp 11; 
[11] Popescu N, Ielenicz M. Relief of Romania (in Romanian), in Scientific Ed., Bucharest,Romania 1974;

[12] Donisă, I. The Pliocene-Quaternary Evolution of the Bistrita Valley (in Romanian), Romania, 1966;

[13] Grasu C, Miclăuş C, Brânzilă M, Boboş I. Sarmatian in the Eastern Carpathian Foreland Basin System (in Romanian). Ed Tehnică, Romania, 2002;

[14] Iosep I. ,Ursu C. - E. , Pălăgheanu Simona. The Plans of the Bucovina District in 72 sections, compiled after geometric pick-ups in the years 1773, 1774, 1775 by the Department of General Staff (in Romanian), Ed. Karl A. Romstorfer, Suceava, Romania, 2011, sections: 62, 70;

[15] Aspinall R, Pearson D. Integrated geographical assessment of environmental condition in water catchments: Linking landscape ecology, environmental modelling and GIS. Journal of Environmental Management. 2000, pp299-319;

[16] Baker WL, Cai Y. The r. le programs for multiscale analysis of landscape structure using the GRASS geographical information system. Landscape ecology, 1992, pp 291-302;

[17] Nicolae, I. Spatial and temporal evolution of landscapes and rural patrimony in Subcarpathians between Râmnicu Sărat and Buzău (in Romanian), Bucharest, Romania, 2011;

[18] Crăcea T. The dynamics of the geographic landscape reflected in the cartographic documents in the Depression of Sibiu (in Romanian), Ed. Univ. "Lucian Blaga", Sibiu, Romania, 2008. 